\title{
Case Report: Pediatric pharmacobezoar with subacute
}

\section{intestinal obstruction [version 1; peer review: 1 approved, 1}

\section{approved with reservations]}

\author{
Mahnaz Hakeem¹, Heeramani Lohana1', Sarwat Urooj¹, Sheraz Ahmed (iD)2 \\ ${ }^{1}$ Pediatrics and Child Health, Aga Khan Maternal and Child Care Centre, Hyderabad, Sindh, 71000, Pakistan \\ ${ }^{2}$ Pediatrics and Child Health, Aga Khan University Hospital, Karachi, Sindh, 74200, Pakistan
}

V1 First published: 25 Aug 2020, 9:1037

https://doi.org/10.12688/f1000research.25441.1

Latest published: 02 Nov 2021, 9:1037

https://doi.org/10.12688/f1000research.25441.2

\section{Abstract}

Bezoars are an undigested mass causing an intraluminal obstruction in children. Pharmacobezoars are formed from medicines or their vehicle, considered as a less frequent type observed in children. Our objective is to report a relatively rare entity as a potential cause of intestinal obstruction in children. Here we report a case of 13-year-old girl with a history of herbal medicine intake who presented with persistent vomiting and abdominal distension. She was diagnosed with acute intestinal obstruction and managed conservatively without any complications. The patient became stable within two days so was discharged home. We found that ineffective history could lead to a delay in diagnosis and management. Clinicians should have a high index of suspicion for pica and psychiatric disorders, especially in adolescent children.

Keywords

bezoar, pharmacobezoar, intestinal obstruction, children.

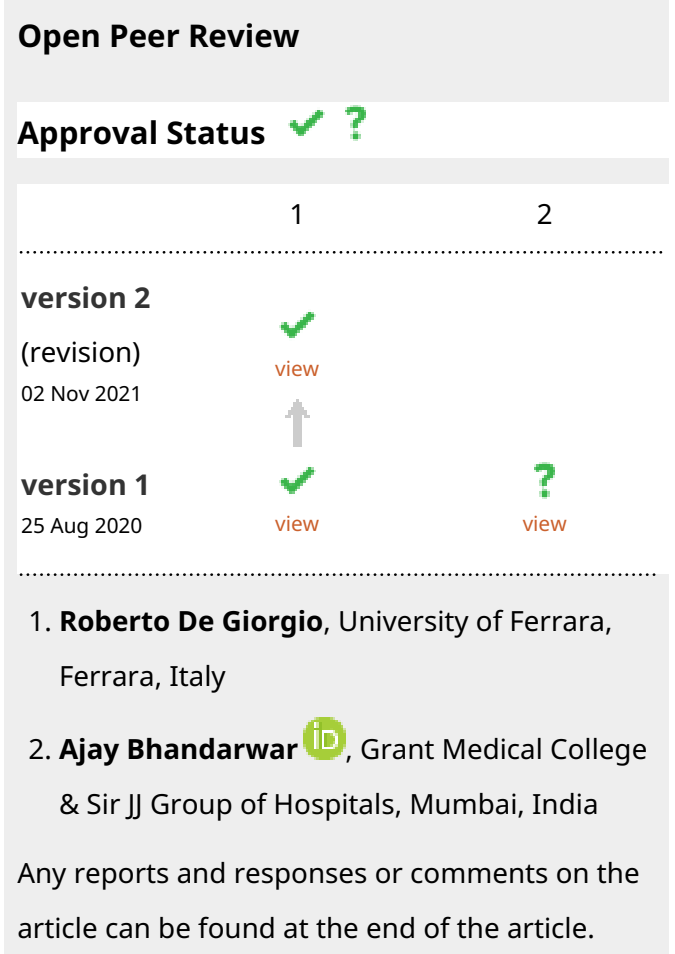

Corresponding author: Heeramani Lohana (heeramani.lohana@aku.edu)

Author roles: Hakeem M: Investigation, Writing - Original Draft Preparation; Lohana H: Investigation; Urooj S: Investigation; Ahmed S: Writing - Review \& Editing

Competing interests: No competing interests were disclosed.

Grant information: The author(s) declared that no grants were involved in supporting this work.

Copyright: $(2020$ Hakeem $\mathrm{M}$ et al. This is an open access article distributed under the terms of the Creative Commons Attribution License, which permits unrestricted use, distribution, and reproduction in any medium, provided the original work is properly cited.

How to cite this article: Hakeem M, Lohana $\mathrm{H}$, Urooj S and Ahmed S. Case Report: Pediatric pharmacobezoar with subacute intestinal obstruction [version 1; peer review: 1 approved, 1 approved with reservations] F1000Research 2020, 9:1037

https://doi.org/10.12688/f1000research.25441.1

First published: 25 Aug 2020, 9:1037 https://doi.org/10.12688/f1000research.25441.1 


\section{Introduction}

The word bezoar is derived from the Persian word, or Arabic word Badzehr, which both refer to antidote ${ }^{1}$. It is defined as the accumulation of undigested ingested material leading to the formation of a mass. Its most common site is the stomach followed by the intestines. The risk of bezoars is higher in children with altered gastrointestinal anatomy, altered motility, and psychiatric disorders. It is further classified by the composition of accumulated material into phytobezoar containing food particles from plant origin, trichobezoar made of hair, lactobezoar formed from milk concretion, and pharmacobezoar formed from medicines or their carrier material ${ }^{2}$. Phytobezoars are the most common among all. Pharmacobezoars are a rare cause of mechanical obstruction of the gastrointestinal tract, and are hence difficult to diagnose. Drugs commonly observed causing bezoar formation are antacids, such as aluminum hydroxide and sucralfate, but they may be caused by other medications, including nifedipine and cholestyramine. Here, we report a case of young girl presenting with intestinal obstruction secondary to excessive intake of herbal medicine. Her diagnosis was delayed for a week despite visiting multiple hospitals due to the paucity of proper history intake.

\section{Case report}

A 13-year-old girl presented to the emergency room of our hospital with a complaint of abdominal pain for six days. She had a history of eating 30 ayurvedic digestive tablets to relieve her indigestion 1 day prior to the onset of abdominal pain. The pain was moderate to severe in intensity, more in the umbilical region, non-radiating, associated with vomiting, and refusal to feed. The patient was taken to a local hospital where intravenous antiemetic dimenhydrinate 50mg stat was given, along with intravenous fluids. An X-ray of the abdomen was done at that time showing distended bowel loops with significant fecal impaction. The patient was given laxative sodium picosulfate $7.5 \mathrm{mg}$ stat and discharged after 4 hours.

Two days later, the patient developed persistent vomiting along with constipation. She was taken to another local hospital where an X-ray of the abdomen was performed showing multiple air-fluid levels. The patient was restricted to oral intake both solids and liquids, an intravenous line was maintained, intravenous fluids and antibiotic ceftriaxone (2 gram once daily) were given, and a nasogastric tube was passed. Surgical opinion was sought at this time and surgical exploration was planned; however, this was refused by the family and the patient was taken to our hospital next day.

At the time of presentation in our hospital, the patient was vitally stable, pale-looking with a nasogastric tube placed in the right nostril. Her abdomen was soft, distended with centrally placed umbilicus and gut sounded sluggish on auscultation. Otherwise, she had no visceromegaly. The patient's drain attached to the nasogastric tube collected $850 \mathrm{ml}$ greenish aspirates over 8 hours. Visual assessment of the aspirated fluids showed particles of ingested medicine. Basic laboratory workups, including complete blood count, electrolytes, and creatinine, were performed (Table 1). X-ray of the abdomen done at our hospital showed a deeply placed nasogastric tube with distended bowel loops (Figure 1 and Figure 2). The nasogastric tube was removed and the patient was kept on intravenous ceftriaxone ( 1 gram twice daily) and metronidazole $(250 \mathrm{mg}$ every 8 hours for 3 days). Surgical consultation was reviewed and after 6 hours she was allowed liquids and foods orally, initially for liquids then after 8 hours solid food was given.

The patient passed stool and had no issues of vomiting, so she was discharged on the second day of admission after dietary

Table 1. Laboratory results with normal ranges.

\begin{tabular}{|l|l|l|}
\hline Laboratory test & Observed values & Reference range \\
\hline Hemoglobin & $11.4 \mathrm{~g} / \mathrm{dl}$ & $12-14 \mathrm{~g} / \mathrm{dl}$ \\
\hline Total Leukocyte count & $13 \times 10^{9} / \mathrm{L}$ & $4-10 \times 109 / \mathrm{L}$ \\
\hline Neutrophil count & $62 \%$ & $54-62 \%$ \\
\hline Lymphocyte count & $26 \%$ & $25-33 \%$ \\
\hline Platelets & $362 \times 10^{9} / \mathrm{L}$ & $\times 10^{9} / \mathrm{L}$ \\
\hline Creatinine & $0.5 \mathrm{mg} / \mathrm{dl}$ & $0.5-1 \mathrm{mg} / \mathrm{dl}$ \\
\hline Creactive protein & $9.9 \mathrm{mg} / \mathrm{dl}$ & $0-0.5 \mathrm{mg} / \mathrm{dl}$ \\
\hline $\begin{array}{l}\text { SGPT (serum glutamic- } \\
\text { pyruvic transaminase) }\end{array}$ & $36 \mathrm{IU} / \mathrm{L}$ & $12-45 \mathrm{IU} / \mathrm{L}$ \\
\hline Sodium & $143 \mathrm{mmol} / \mathrm{L}$ & $136-145 \mathrm{mmol} / \mathrm{L}$ \\
\hline Potassium & $3.3 \mathrm{mmol} / \mathrm{L}$ & $3.5-5.1 \mathrm{mmol} / \mathrm{L}$ \\
\hline Chloride & $105 \mathrm{mmol} / \mathrm{L}$ & $98-107 \mathrm{mmol} / \mathrm{L}$ \\
\hline Bicarbonate & $19.4 \mathrm{mmol} / \mathrm{L}$ & $20-31 \mathrm{mmol} / \mathrm{L}$ \\
\hline
\end{tabular}




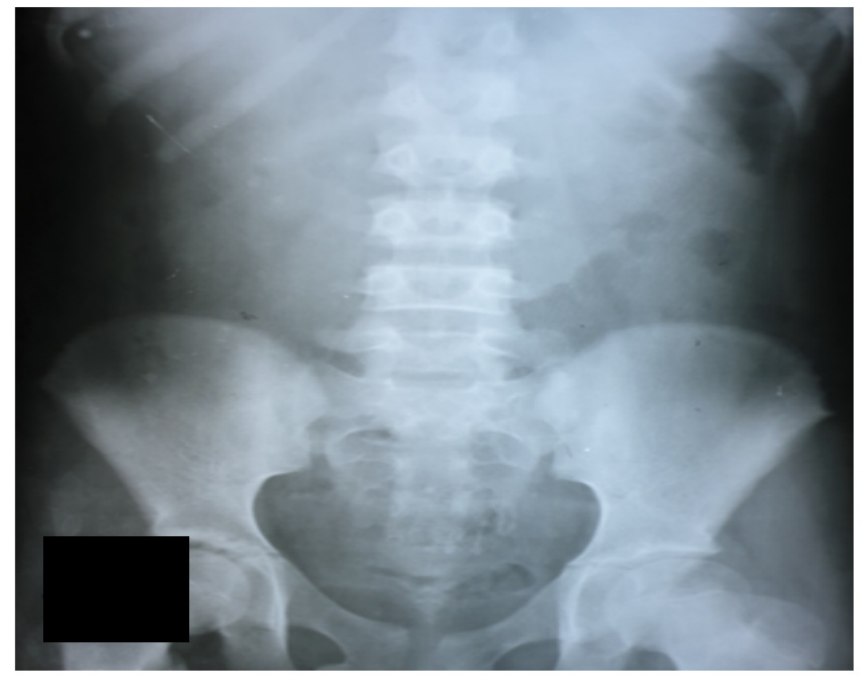

Figure 1. X-ray of the abdomen showing diffuse fecal loading.

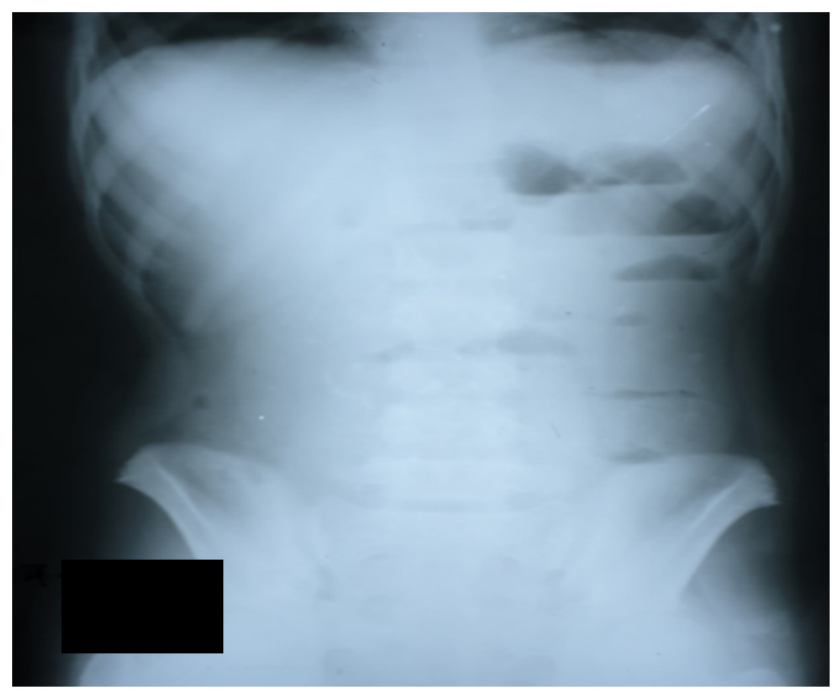

Figure 2. X-ray of the abdomen multiple air fluid levels.

counseling. X-ray abdomen showed normal gaseous shadows (Figure 3). Scheduled follow up after 10 days, showed that the patient was in good condition.

\section{Discussion}

Mechanical obstruction caused by pharmacobezoars accounts for $4 \%$ of all patients with intestinal obstruction, often subacute obstruction $^{3}$. Mechanisms involved in formation of pharmacobezoars include dysmotility secondary to an anatomical defect or anticholinergic effects of the drug, a massive quantity of drug intake, or its hydrophobic nature ${ }^{4}$. Ingestion of medicine in huge quantities may be secondary to mental retardation, psychiatric disorders, or suicidal intentions. There is limited published data of pediatric pharmacobezoar internationally in this regard with no documented evidence in the local population in Pakistan.

Imaging modality used in diagnosis of pharmacobezoars includes plain radiographs and ultrasonography, and more advanced techniques, such as CT scan. Endoscopy may be considered as a diagnostic tool as well as a therapeutic option for an impacted bezoar. Visual assessment and biopsy of fragmented bezoar tissue are also helpful in diagnosis.

Treatment options vary from a non-surgical approach, including conservative management, to laparoscopic approach or open laparotomy in rare circumstances. Non-surgical options include dissolution of bezoar, fragmentation, gastric lavage, 


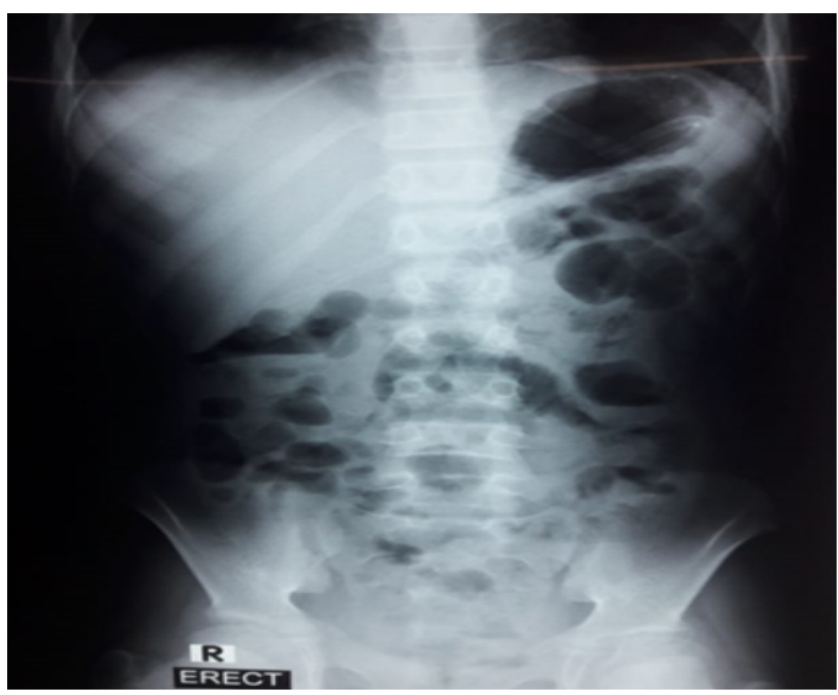

Figure 3. X-ray of the abdomen showing normal gaseous shadows after treatment.

or endoscopic removal, which is considered as the first line in management ${ }^{5}$. Irrigation of normal saline along with the withdrawal of the causative medicine has been effective in some cases $^{6}$. One study has showed that the dissolution of pharmacobezoars was performed with cellulose and diet coke along with multiple medications ${ }^{1}$.

Our patient had a history of intake of herbal medicine composed of tamarind, guava, mint, and other spices. There was an unintentional massive intake of tablets within a short time, leading to its concretion in the small intestine. She was diagnosed with $\mathrm{X}$-ray of the abdomen and managed with normal saline irrigation and abstinence of the culprit medicine as we had a lack of availability of endoscopy for pediatrics in our city.

If left untreated, bezoar may lead to perforation, peritonitis, weight loss, ulcer, anorexia, and constipation ${ }^{7}$. Endoscopic removal of bezoar may lead to aspiration, particularly in the case of fragmentation. Timely management is key to avoid these complications. Risk factors attributing to the development of bezoars, such as gastrointestinal motility disorders, drug interactions and psychiatric illnesses, should be addressed appropriately to avoid recurrent bezoars.

\section{Conclusion}

Bezoars account for a sporadic number of patients with mechanical intestinal obstruction. History of pica should be evaluated in patients with bezoars. Proper dietary counseling, adequate chewing, and psychotherapy may prevent this condition.

\section{Consent}

Written informed consent to publish the case report along with images was obtained from the father of the patient.

\section{Data availability}

All data underlying the results are available as part of the article and no additional source data are required.
1. Eng K, Kay M: Gastrointestinal Bezoars: History and Current Treatment Paradigms. Gastroenterol Hepatol (N Y). 2012; 8(11): 776-778 ISSN 1554-7914; 1554-7914.

PubMed Abstract | Free Full Text

2. Simpson SE: Pharmacobezoars Described and Demystified. Clin Toxicol (Phila). 2011; 49(2): 72-89 ISSN 1556-9519; 1556-3650. PubMed Abstract | Publisher Full Text

3. Gandhi S, Arora E, Bhandarwar A, et al.: When a Cure Becomes the Pathology: Mechanical Bowel Obstruction due to Herbal Pharmacobezoar. A Case Report with Review of Literature. Clin J Gastroenterol. 2018; 11(5): 396-400 ISSN 1865-7265; 1865-7265.

PubMed Abstract | Publisher Full Text

4. Gori F, Cirronis M, Ieri A, et al.: Importance of Abdomen CT Scan and
Gastroscopic Pharmacobezoar Removal Following Massive Acute Drug Overdose. Clinical Toxicology. 2015; 53(4).

Reference Source

5. Castle SL, Zmora O, Papillon S, et al.: Management of Complicated Gastric Bezoars in Children and Adolescents. Isr Med Assoc J. 2015; 17(9): 541-544 ISSN 1565-1088.

PubMed Abstract

6. Portuguez-Malavasi A, Aranda JV: Antacid Bezoar in a Newborn. Pediatrics. 1979; 63(4): 679-680 ISSN 0031-4005; 0031-4005. PubMed Abstract

7. Hon KL, Cheng J, Chow CM, et al.: Complications of Bezoar in Children: What is New? Case Rep Pediatr. 2013; 2013: 523569 ISSN 2090-6803. PubMed Abstract | Free Full Text 


\section{Open Peer Review}

\section{Current Peer Review Status:}

\section{Version 1}

Reviewer Report 30 November 2020

https://doi.org/10.5256/f1000research.28074.r73868

(C) 2020 Bhandarwar A. This is an open access peer review report distributed under the terms of the Creative Commons Attribution License, which permits unrestricted use, distribution, and reproduction in any medium, provided the original work is properly cited.

\section{Ajay Bhandarwar \\ Department of General Surgery, Grant Medical College \& Sir JJ Group of Hospitals, Mumbai, Maharashtra, India}

1. History and progression are detailed, however, the need for ayurvedk]ic tablet ingestion has not been mentioned in the first place. Indigestion associated 30 tablet intake seems unlikely.

2. Does the patient have any other previous Psychiatric illness history or Family history of the same? This is needed for reading practitioners to understand the association of Bezoars with psychiatric illness even at a young age.

3. The productive finding is that conservative Management can be approached in such cases, however, it should not be generalised treatment. Hence pre-op scoring systems can be employed to give a trial of conservative management in the future.

4. Management seems to be a basic conservative line of treatment, with no new findings. But reaffirmation of known treatment modality. Image of Nasogastric tube aspirate of $800+c c$ would have been more impactful.

Overall, for inexperienced practitioners, it is a good read to understand the importance of a conservative trial and immediate stabilisation management steps. However, the above-mentioned points might make it more worthwhile a read.

Is the background of the case's history and progression described in sufficient detail? Partly

Are enough details provided of any physical examination and diagnostic tests, treatment given and outcomes?

Yes 
Is sufficient discussion included of the importance of the findings and their relevance to future understanding of disease processes, diagnosis or treatment?

Partly

Is the case presented with sufficient detail to be useful for other practitioners?

Yes

Competing Interests: No competing interests were disclosed.

Reviewer Expertise: Minimal Access surgery in GI, Endocrine and HPB surgeries.

I confirm that I have read this submission and believe that I have an appropriate level of expertise to confirm that it is of an acceptable scientific standard, however I have significant reservations, as outlined above.

Reviewer Report 09 October 2020

https://doi.org/10.5256/f1000research.28074.r72257

(c) 2020 De Giorgio R. This is an open access peer review report distributed under the terms of the Creative Commons Attribution License, which permits unrestricted use, distribution, and reproduction in any medium, provided the original work is properly cited.

\section{Roberto De Giorgio}

Department of Morphology, Surgery and Experimental Medicine, St. Anna University Hospital, University of Ferrara, Ferrara, Italy

Very interesting, well detailed case.

1. I suggest the Authors to improve the quality of the images presented in this case report.

2. Please note that Fig. 1 does not match with the text (no evidence of the N-G tube...where is it ?).

3. Explain why a CT scan of the abdomen was not performed.

Is the background of the case's history and progression described in sufficient detail? Yes

Are enough details provided of any physical examination and diagnostic tests, treatment given and outcomes?

Yes

Is sufficient discussion included of the importance of the findings and their relevance to future understanding of disease processes, diagnosis or treatment? 
Is the case presented with sufficient detail to be useful for other practitioners?

Yes

Competing Interests: No competing interests were disclosed.

Reviewer Expertise: Gastrointestinal motility and functional bowel disease.

I confirm that I have read this submission and believe that I have an appropriate level of expertise to confirm that it is of an acceptable scientific standard.

The benefits of publishing with F1000Research:

- Your article is published within days, with no editorial bias

- You can publish traditional articles, null/negative results, case reports, data notes and more

- The peer review process is transparent and collaborative

- Your article is indexed in PubMed after passing peer review

- Dedicated customer support at every stage

For pre-submission enquiries, contact research@f1000.com 